\title{
Redesign of an interior HVAC system in order to limit the spread of the COVID-19 virus in co-working spaces
}

\author{
A.D. Handoyo \\ Telkom University, Bandung, Indonesia \\ E. Wicaksono \\ Universitas Pelita Harapan, Tangerang, Indonesia
}

\begin{abstract}
The existence of the COVID-19 pandemic has affected the world of design. The current habit and design process are pushed to be able to adapt new habits in the post-pandemic era. Public areas such as shared workspace have become one of the prioritized places for implementing health protocols as they work collectively. This study aims to identify the most optimal solution so that the existing building design can meet the health protocol standards in the new era of normality. Through precedent study, this research analyzes the ventilation system of co-working space in Bandung. The observation focused on public areas that have the longest duration of use. It was found based on the study that the design of open workspaces is relatively safe with cross ventilation to dilute the air. However, enclosed space design requires additional attributes such as UVC lamps to kill germs to clean the air.
\end{abstract}

Keywords: UVC, COVID, co-working space, air conditioning, interior design

\section{BACKGROUND}

The condition of the SARS-CoV-2 pandemic (hereafter referred to as COVID virus) demands the manager of buildings to adapt the old design to new normal requirements through a process of a redesign (Yatmo 2020; Hatmoko 2020; Tabinas 2020). In general, people spend most of their time at home (Gilrandy et.al. 2020) or the office/co-working space (Turner 1971; Heidegger 1971; Pramadesty 2018). Strong airflow from an air conditioner may spread a droplet that carries the virus (Lu et al. 2020). The COVID virus also tends to be stable and has longer life outside of its host body in a low temperature and humid environment such as in a space with an air conditioner (Hillside 2020). The risk of spreading a disease will expand if there is less air exchange inside the room, just like SARS cases at Hotel Metropole Hongkong in 2003 and the emergence of new contagion clusters in offices.

For the sake of energy efficiency, some building managers only recycle air that has been cooled down in the room. If not designated adequately, the air conditioning system may become a primary incubator as well as a source of disease.

This case is different with an air conditioning system in an airplane or hospital that is specifically designed with HEPA (High-Efficiency Particulate Air) system that can block particles with a diameter of 0.3 microns or higher, with $99 \%$ or even higher efficiency (Schoen 2014). However, this HEPA filter has a limitation, which is its expensive price. An alternative system for artificial airing is required and proposed to prevent the spread of the virus at an affordable price.

This research aims to analyze the airing system inside an existing design in adapting new habitual activities, by taking a study to the design of co-working space in the city of Bandung. Co-working space is chosen not only because this place serves as an office, but also as a home office concept that is supported by various facilities. 

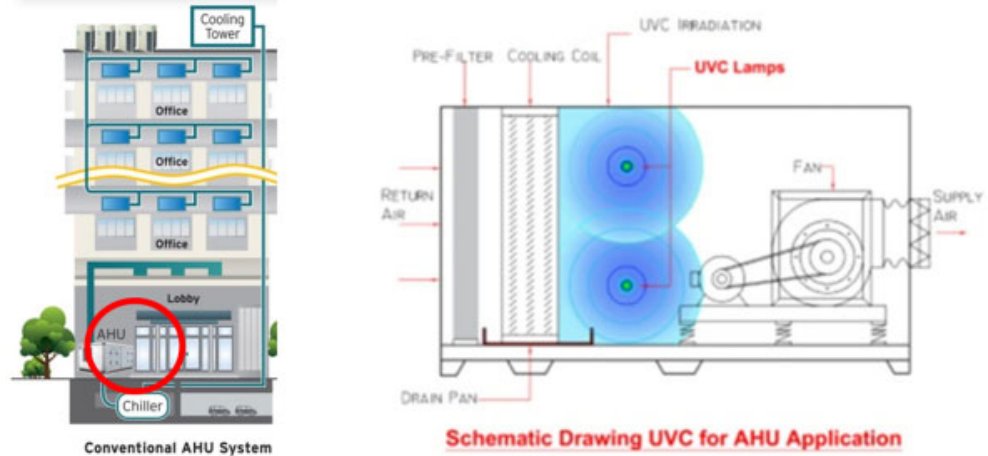

Figure 1. The placement of UV ray inside AHU system.

Table 1. Comparison between the adaptation of new habit in controlling the risk.

\begin{tabular}{|c|c|c|c|}
\hline Effort & Avoid & Shift & Improve \\
\hline $\begin{array}{l}\text { Elimination } \\
\text { (remove the virus) } \\
\text { Engineering controls }\end{array}$ & $\begin{array}{l}\text { 1. Room with high density } \\
\text { (crowded space) } \\
\text { 2. Rooms with closes air } \\
\text { conditioning system } \\
\text { without new airflow. } \\
\text { 3. Use of sharing } \\
\text { application. }\end{array}$ & $\begin{array}{l}\text { 1. Physical distancing. } \\
\text { 2. Pressure control } \\
\text { inside a room. } \\
\text { 3. Vertical separation } \\
\text { between clean and } \\
\text { dirty. } \\
\text { 4. Optimizing natural } \\
\text { ventilation to dilute } \\
\text { the air. } \\
\text { 5. Routine cleaning. }\end{array}$ & $\begin{array}{l}\text { 1. Technology to kill } \\
\text { virus: UV, plasma, } \\
\text { ozone. } \\
\text { 2. Technology } \\
\text { adaptation to filter } \\
\text { virus: HEPA. }\end{array}$ \\
\hline
\end{tabular}

Morawska et al. (2020) argues that health protocols in adapting new habits can be divided into four categories according to their level of effectivity: virus elimination as a source of disease, engineering control, administrative control, and personal protection. This study focuses on the first and second level because is more relevant to the design and effectivity in limiting the spread of the virus. Many researchers suggest that this protocol be implemented in the home (Heath 2020; Gilrandy et al. 2020) and office (Serres 2020; Libanori 2020). Both categories can be divided further into three groups in its application, some need to be avoided, shifted, and improved from existing condition (TUMI 2020).

ASHRAE (American Society of Heating, Refrigerating and Air-Conditioning Engineers) recommends the counter measure of COVID spread by using HVAC (Schoen 2014). First, to implement air dilution with optimizing natural airing with opening doors and windows, and second, to control the direction of air from the supply point back to the return point, regulate the air inside the room, design personal ventilation openings, personal airing inside the room, air filtering, and UVGI (). Considering the dangers of direct UVGI exposure to humans, UVGI is installed as an additional filter from the centralized air conditioning which is placed on the AHU system.

This proposition uses ultraviolet (UV) ray that is proven to deactivate the virus. A correct application is needed so this UV ray can be effective in dealing with COVID-19 pandemic inside a building system (Hibaru 2020).

\section{METHOD}

This research is conducted through observation and surveys simultaneously with descriptive analytics about HVAC system in Bandung Digital Valley (BDV). BDV was designed as a coworking 
space especially for startups in the technology industry. In the initial stage, observations are made to analyze the ventilation system in the room that has the most users and the longest duration of use. The analysis is focused on the direction of air movement by comparing where the position of the air supply and the return point. Therefore, the movement of air in the room can be designed in such a way that it doesn't mix clean air with dirty air. This research is exploring solutions on how existing conditions can be improved so that they can minimize the spread of COVID by engineering the spatial planning, ventilation system, and minimizing user capacity. This research compares the before and after condition from the redesign proposal in the shared workspace and communal space.

\section{RESULT AND DISCUSSION}

Based on the observation, it was found that shared working space has the most frequent use and the longest duration of use. Almost all rooms in BDV are enclosed spaces using air conditioning as a ventilation system. Shared workspace and communal space are not exceptions. Coworking space in BDV is integrated inside a single building utilizing centralized air conditioning as the primary airing system and is supported by a split system in several parts. Air conditioning works by sucking air from the room then mixes with clean air from outside. The mixture from Cooling Tower enters through the Air Handling Unit (AHU), is filtered, and then distributed through air evenly from each AHU to every room. The situation of working space in BDV is shown in Figure 2.

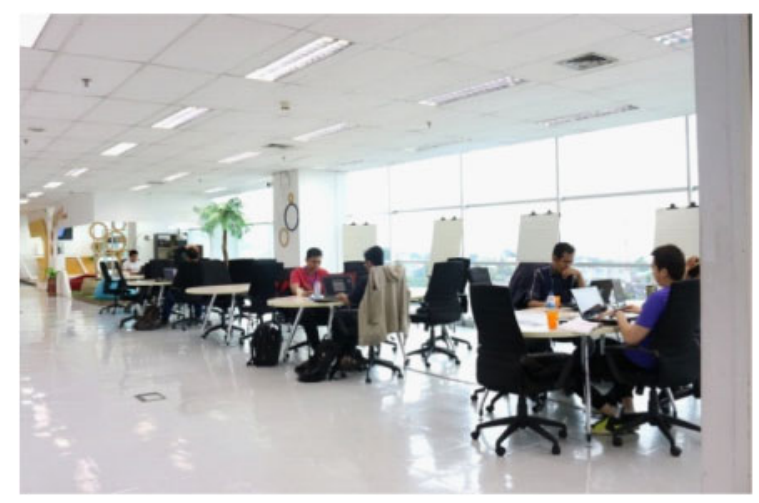

Figure 2. Existing environment inside a coworking area in BDV.

The working desk is arranged in a group with a capacity of six people. Two people in the middle are facing each other and there are two others on each side, as shown in Figure 3. In the existing design, clean air is coming out of the supply outlet on the ceiling (blue color). Clean air mixes with the air in the room and is used (orange color) to become dirty air (light green color). Then, the dirty air is sucked in by a return inlet on the ceiling. Air movement has the potential to spread droplets that have already fallen and may contain the virus to mix with clean air on the ceiling. Also, with this close proximity of layout (less than 1 meter), each person has a greater exposure from infected individual to droplets (see dark green color) (Nicas \& Jones 2009; Li 2011).

Figure 4 illustrates two situations that can be implemented to adapt new habits in BDV. The first and the best scenario is to open the window to dilute the inside air with the outside (see light blue color) (Sun et al. 2011). The amount of air can be controlled so that the flow of cross ventilation that enters the room is exactly what the occupants need to feel comfortable.

The second scenario, if the first scenario is not possible because of using the fixed window and air conditioner, an AHU system must be equipped with UVGI irradiation as a filter to clean air contaminated by the COVID virus (Schoen 2014). This system must also be modified in order 


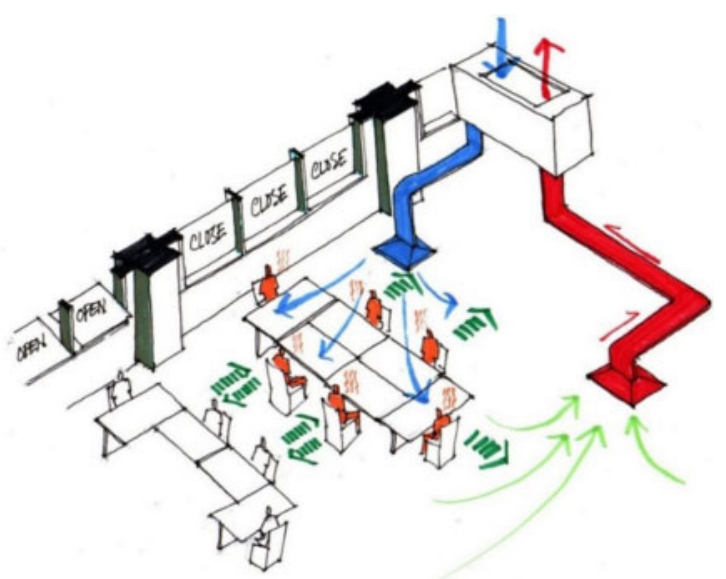

Figure 3. An illustration of existing layout of working space and HVAC system in BDV.

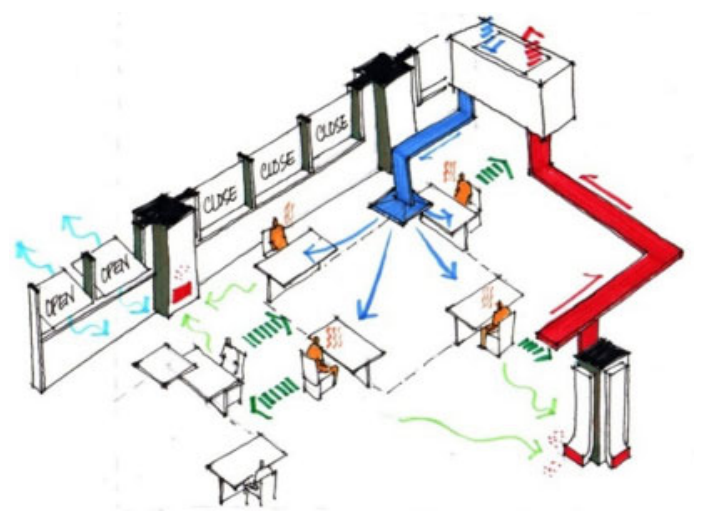

Figure 4. An illustrated simulation of adapting the new habit in BDV.

to optimize fresh air. Learning from the air conditioning system in the hospital, the supply outlet remains to be placed on the ceiling while the return inlet must be modified as close as possible to the floor. By following the law of gravity, zoning of air in space is divided into two parts, namely clean air at the top, and dirty air (containing droplets/microdroplets) is at the bottom. The dirty air collected below is not expected to disperse and can be sucked in directly at the return point (Fennelly et al. 2004; Wainwright et al. 2009). Of course, changes in the position of the inlet return must adjust the conditions and placement of walls, columns, and other interior elements.

Regarding the arrangement of the furniture layout, the suggestions are: the working area is to be placed radially below the suppy outlet of the clean air (dark blue color) to create a positive pressure room that can be used by the occupants. The radial arrangement of the working table results in maintaining a safe distance between users, as mentioned by Nicas and Jones (2009) and Li (2011). Using a zigzag sitting pattern can minimize the air flow that may contain the virus to the person behind. This experiment and solution will be more successful if it is implemented together with new normal habits and other health protocols such as wearing masks, washing hands frequently, and/or using face shield. 


\section{CONCLUSION}

Based on this study, it is found that utilization of an air conditioning system in a close room increases the risk of spreading the virus. First, the impact can be reduced by putting in more clean air to dilute the air in the interior. This effort can be done by optimizing natural ventilation through window openings and artificial airing system if it is not possible to open the window. On the other hand, introducing more fresh air will have an impact on the performance of a heavier AC engine. Second, if the building is using a central air conditioner, the UVG system can be integrated into the AHU. In addition, the placement of lamps in AHU ensures the UV rays do not disturb the occupants. In the interior, the supply and return point are designed in such way so the air can be circulated, UV-ed, filtered, as quick as possible. The return inlets are positioned as low as the floor level to clean up the fallen droplet. Therefore, the rooms are designed to separate the clean air and dirty (or may contaminated) air. Third, redesigning the layout of workspace. Creating zig-zag seating arrangement not only reduces rooms capacity but also increases a safe distance between occupants (more than 1-3 meters). This study recommends that other studies be conducted related to how to create an air conditioning system that still optimizes fresh air but has high energy efficiency.

\section{REFERENCES}

Fennelly, K.P., J.W. Martyny, K.E. Fulton, I.M. Orme, D.M. Cave, and L.B. Heifets. 2004. Coughgenerated aerosols of Mycobacterium Tuberculosis: A new method to study infectiousness. American Journal of Respiratory and Critical Care Medicine 169:604-609.

Gilrandy S. and Apriliyanthi, S. Atidesa. A. 2020. Dream House that Respond to Pandemic Situation. Webinar. Indonesia, May 16, 2020

Hatmoko, A. 2020. Isu Utama Pasca Covid. Berubahkah Tatanan Arsitektur Pasca Covid-19? Webinar. IAI Sumatera Barat.

Heath, O. Biophillic Design. How to create interior spaces that enhance our physical and mental wellbeing. Webinar. Singapore, May 18, 2020

Heidegger, M. 1971. Poetry, Language, Thought. Building, Dwelling, Thinking. New York: Harper \& Row

Ibold, S., Medimorec, N., Wagner A. Peruzzo, J. 2020. The Covid 19 Outbreak and Implications to Sustainable Urban Mobility. TUMI Transformative Urban Mobility Initiative. Retrieved 16:23, July 23, 2020 from https://www.transformative-mobility.org/news/the-covid-19-outbreak-and-implications-topublic-transport-some-observations

Infrastructure Guidance for COVID-19/Alternate Care Sites. June 9, 2020. The HILLSIDE. Retrieved 07:51, August 1, 2020 from https://thehillside.info/index.php?title=Infrastructure_Guidance_for_COVID19/Alternate_Care_Sites\&oldid=2128.

Li, Y. 2011. The secret behind the mask. (Editorial.) Indoor Air 21(2):89-91.

Libanori, M. 2020. The Power of Colors. Smarter Impact: Webinar Series. Webinar. Singapore, May 7, 2020

Lu, J., Gu, J., Li, K., Xu, C., Su, W., Lai, Z....Yang, Z. 2020. COVID-19 Outbreak Associated with Air Conditioning in Restaurant, Guangzhou, China, 2020. Emerging Infectious Diseases, 26(7):1628-1631. https://dx.doi.org/10.3201/eid2607.200764.

Memarzadeh, Farhad. 2011. Literature review of the effect of temperature and humidity on viruses. ASHRAE Transactions 117(2).

Morawska, J.W. Tang, et al. 2020. How can airborne transmission of COVID-19 indoors be minimised?, Environment International (2020), doi: https://doi.org/10.1016/j.envint.2020.105832.

Nicas, M. and R.M. Jones. 2009. Relative contributions of four exposure pathways to influenza infection risk. Risk Analysis 29:1292-303.

Pramedesty, R., et al. 2018. Co-Working Space Sebagai Solusi Kebutuhan Ruang Kerja Berdasarkan Karakteristik Startup Kreatif. Idealog: Ide dan Dialog Desain Indonesia, [S.1.], 3(1):50-60.

Schoen, L. 2014. ASHRAE Position Document on Airborne Infectious Diseases. Atlanta: ASHRAE

Hibaru. UVLAMP \& UVC-Membunuh Bakteri, Virus, Jamur, Lumut DLL (2020, June 9). PT Hibaru. Retrieved 21:51, August 1, 2020 from http://www.hibaru-online.com/uv-lamp-uvc-membunuh-bakteri-virus-jamurlumut-dll

Serres, A. 2020. Human Centric Design. Smarter Impact: Webinar Series. Webinar. Singapore, May 5, 2020 
Sun Y., Z. Wang, Y. Zhang, and J. Sundell. 2011. In China, students in crowded dormitories with a low ventilation rate have more common colds: Evidence for airborne transmission. PLOS ONE 6(11):e27140.

Tabinas, J. 2020. The Response of Architecture to Pandemic: How COVID Impact the Design? The Architecture of/in/on/from the new normal. Webinar. Malaysia, May 9, 2020

Turner, J. 1971. Housing by People: Towards the autonomy in Building Environments. New York: Pantheon Books

Wainwright, C.E., M.W. Frances, P. O’Rourke, S. Anuj, T.J. Kidd, M.D. Nissen, T.P. Sloots, C. Coulter, Z. Ristovski, M. Hargreaves, B.R. Rose, C. Harbour, S.C, Bell, and K.P. Fennelly. 2009. Cough-generated aerosols of Pseudomonas aeruginosa and other Gram-negative bacteria from patients with cystic fibrosis. Thorax 64:926-31.

Yatmo, Y. 2020. Evidence Based Design:Arsitektur Setelah Covid-19. Berubahkah Tatanan Arsitektur Pasca Covid-19? Webinar. IAI Sumatera Barat, April 29, 2020. 